\title{
Faculty and student representations of academic writing at Spanish universities / Las representaciones de profesores y estudiantes sobre la escritura académica en las universidades españolas
}

\author{
Montserrat Castelló ${ }^{\mathrm{a}}$ and Mar Mateos ${ }^{\mathrm{b}}$ \\ ${ }^{a}$ Universitat Ramon Llull; ${ }^{b}$ Universidad Autónoma de Madrid
}

(Received 30 April 2014; accepted 4 November 2014)

\begin{abstract}
Research on academic writing has been the focus of several international publications, seminars and conferences during the last decades. However, knowledge of the practices and conceptions, along with the status of writing in higher education, is quite disparate depending on the contexts and traditions. In this paper, we survey the research on representations of academic writing internationally as well as the background of the European Writing Survey (EUWRIT), which has two versions, one targeted at students and the other at faculty, both of which were used in our research project. This paper explains the rationale of the scales and describes the items and the international underpinnings which endorse their development. Then, the characteristics of the sample, which were shared by all the studies included in this special issue, are outlined. Participants were 1,044 students and 280 faculty in different disciplines at nine Spanish universities. The theoretical structure and reliability of each of the scales are analysed. The paper ends with the descriptive general results regarding faculty and students and the differences observed based on some characteristics of participants from different disciplines.
\end{abstract}

Keywords: academic writing; conceptions of writing; representations of writing; higher education

Resumen: El estudio de la escritura académica ha sido el centro de interés de publicaciones seminarios y conferencias de alcance internacional. Sin embargo, el conocimiento de las prácticas y concepciones y del estatus que la escritura tiene en la Educación Superior es muy diferente según los contextos y las tradiciones. En este artículo se revisan los trabajos sobre las representaciones de la escritura académica en el contexto internacional y se presentan los cuestionarios Encuesta Europea sobre la Escritura Académica (EEEA) para profesores y estudiantes, utilizados en el presente proyecto de

English version: pp. 1-12 / Versión en español: pp. 13-24

References / Referencias: pp. 24-27

Translated from Spanish / Traducción del español: Mary Black

Authors' Address / Correspondencia con las autoras: Montserrat Castelló, Facultat de Psicología, Ciències de l'Educació i l'Esport. Blanquerna, Universitat Ramon Llull, C/ Císter, 34, 08022 Barcelona, España. E-mail: montserratcb@blanquerna.url.edu 
investigación. También se describen las características de la muestra a partir de la cual se han realizado los análisis que conforman los artículos del monográfico (1,044 estudiantes y 280 profesores de nueve universidades españolas y se analiza la estructura teórica y la fiabilidad de las escalas. Se analizan los resultados descriptivos generales relativos a profesores y estudiantes y las diferencias observadas en función de algunas características de la muestra en las diferentes disciplinas.

Palabras clave: escritura académica; concepciones sobre la escritura; representaciones sobre la escritura; educación superior

In the past 20 years, the study of academic writing has generated a huge number of publications and has been the focus of several international seminars and conferences (Bazerman et al., 2012). However, knowledge of the practices and conceptions and, indeed, the status of writing in higher education is quite disparate depending on the contexts and traditions.

In English-speaking contexts, primarily English-speaking countries such as the USA and the United Kingdom, teaching writing and analysing writing practices at university was an extremely important topic throughout the entire twentieth century, with exponential growth in the past 50 years. Therefore, its influence on research today is undeniable (Bazerman et al., 2005). Britton's (1970) pioneering claim about the need for students to write functional texts within their disciplines, as well as his claims for the epistemic power of writing, make him a forerunner of the Writing across the Curriculum (WAC) and Writing in the Disciplines (WID) movements in the USA and the Academic Literacies (ACLITS) approach in the United Kingdom (Russell, Lea, Parker, Street, \& Donahue, 2009). This complex, ambitious mission has generated two major avenues of research: (a) one occupied with studying the disciplinary texts and discourses; and (b) one that questions, as in our case, the practices and the texts that are written in university classrooms (Bazerman, 1992; Russell, 1991, 1997). The results of the first avenue of research have enabled us to describe the particular features and functions of the discourse in many disciplines (Hyland, 2005) and scientific (Hyland, 2008; Swales, 2004) or academic genres (Gardner \& Nesi, 2013), which then gave rise to multiple educational proposals (Bazerman, Bonini, \& Figueiredo, 2009). This first avenue also explored students' conceptions of composition processes, either from phenomenological perspectives (Lavelle \& Zuercher, 2001) or based on implicit theories (White \& Bruning, 2005). In the former, the results refer to two opposing approaches to writing which, broadly speaking, correspond to models of uttering or transforming knowledge as described by Bereiter and Scardamalia (1987). In turn, White and Bruning (2005) identified the existence of transmissive and transactional beliefs; the latter are associated with greater cognitive and affective involvement in writing, along with better levels of text organization, idea development and overall writing quality.

The second avenue of research encompasses everything from large-scale studies which analyse and survey national practices in both teaching (Applebee \& Langer, 2013) and evaluating writing (Applebee, 2013), to more qualitative and 
ethnographic studies which evaluate the unique features of these practices and their results (Carroll, 2002; Walvoord \& McCarthy, 2008). Some studies of this kind performed in the United Kingdom within the ACLITS movement have also revealed the multiple discourses that compete in academia and stress the mechanisms that lead faculty and students to prioritize one over the others (Ivanič, 1998; Lea, 2012; Lillis, 1997).

The study by Lea and Street (1998) signalled a turning point by stressing the need to bear in mind the expectations and the way faculty and students interpret writing. Their results point to three major models which can explain the conceptions - often implicit - and practices associated with teaching writing. The first, which focuses on academic skills or techniques, associates the development of the students' competence in academic writing with the mastery of grammar, syntax, spelling and punctuation. The second stresses academic socialization, or students' familiarity with the discourses and genres of the disciplines so they can participate in their cultures. The third model encompasses the first two and seeks academic literacy(ies), meaning that the nature of institutional practices, power relations and their impact on student and faculty identities must also be borne in mind. In recent years, this last conception has enabled the emergence of new writing practices and contexts to be described, which are forcing us to rethink how we teach and deal with writing (Lea, 2012; Lea \& Stierer, 2000; Robinson-Pant \& Street, 2012). This is the backdrop of the studies which have analysed the interactions between the writing practices that predominate in university classrooms and the development of student and faculty identities and positions (Casanave \& Vandrick, 2003; Ivanič, 1998).

In the other non-English-speaking European countries, studies on the conceptions of writing, especially on a large scale, have only appeared more recently and are less common. What is more, the linguistic and cultural diversity, along with the diversity of practices associated with higher education, contribute to a certain dispersion of knowledge in this area. Still, there are major studies on conceptions of the nature of writing which associate it with high levels of stress, especially at the post-graduate and doctoral level (Lonka et al., 2014). They are joined by studies that focus on how teaching in multivocal contexts influences students' attitudes and conceptions and the epistemic use of writing (Dysthe, 2012). The topic of disagreements between faculty and students on their representations and expectations has been a recurrent topic in European research on writing practices. The results of these studies show changes in these representations as students progress towards higher levels of study, which are also mediated by certain disciplinary practices (Delcambre \& Donahue, 2012) and by the institutional changes underway in higher education (Robinson-Pant \& Street, 2012).

In recent years, researchers' interest in crossing boundaries, both linguistic and geographic and cultural, has led to the appearance of initiatives and publications that not only foster a dialogue among different traditions but have also laid the foundations for international cross-cultural projects, especially in the field of academic writing (Castelló \& Donahue, 2012). One of these initiatives was the Learning to Write Effectively (ERN-LWE) ${ }^{1}$ project, which connected researchers 
from 23 European countries. Its results included the development of the European Writing Survey (EUWRIT), which has two versions, one for students and the other for faculty. It is currently available in eight languages, including Spanish, Catalan and Basque, and it was used as the main data-gathering source in the articles in this issue (Chitez, Kruse, \& Castelló, 2015; Kruse, 2013; Kruse \& Chitez, 2012).

In Spain and Latin American countries the interest in and number of publications on the status of academic writing have also increased (Camps \& Castelló, 2013), as have the proposals to teach the writing genres that are used in the different disciplines and at different levels of university education (ÁlvarezAngulo, 1996; Castello, 2007; Castelló, 2009; Perea, 2013; Solé, Teberosky, \& Castelló, 2012; Tolchinsky, 2013). Recently, instruments to analyse students' conceptions of and attitudes towards writing have also been developed (Álvarez, Villardón, \& Yániz, 2010; Villalón \& Mateos, 2009), and research has inquired into specific activities and genres, such as synthesis and argumentation (Álvarez, Villardón, \& Yániz, 2008; Mateos \& Solé, 2009; Mateos et al., 2014) and their relationship with the acquisition of knowledge (Mateos et al., 2011; Mateos, Villalón, de Dios, \& Martín, 2007; Solé et al., 2005). Generally speaking, the results reveal students' difficulties and the absence of epistemic writing assignments in higher education. In parallel, instructional proposals have been designed and analysed in order to help students to appropriate specific genres related either to their professionalization (Roca de Larios \& Serrano, 2011) or to research, such as writing the Bachelor's thesis (Castelló, Inesta, Pardo, Liesa, \& MartínezFernández, 2012; Corcelles, Cano, Bañales, \& Vega, 2013) and research articles (Castello, Inesta, \& Corcelles, 2013). The results of these recent studies point to the development of learning communities in which students can regulate and overcome challenges and tensions and develop their identity as writers (Iñesta \& Castelló, 2012; Oliva \& Milian, 2013).

Despite these and other clearly noteworthy advances, the compartmentalization of Spanish universities into academic disciplines, coupled with the existence of avenues of dissemination which are also highly compartmentalized, hinders knowledge and integration of the different initiatives. This dispersion is compounded by the fact that we have no large-scale studies that describe the status of writing in Spanish universities. With the exception of a handful of isolated cases (Castelló, Mateos et al., 2012; Mateos et al., 2007; Perea, 2013; Solé et al., 2005), we still know very little about when and why our students write in different disciplines, whether they receive help as they manage the composition process or whether only final texts are evaluated, and whether faculty and students understand the same thing when a report, summary or written case study resolution is assigned. With the goal of gaining more insight into these issues, we have developed the studies included in this special issue as part of the Research Network on Academic Writing in Teaching and Learning Processes (Red para la Investigación de la Escritura Académica en los procesos de Enseñanza y Aprendizaje; RIEA-EA) $)^{2}$. This is an initial examination of how students and 
faculty describe their habitual writing practices, along with the conceptions that underpin these practices in different disciplinary contexts.

This first article, which provides the framework for this special issue, presents the characteristics, underpinnings and structure of the instrument used. We shall describe the general representations of academic writing held by faculty and students and relate them to the characteristics of the participants, disciplines and educational levels.

\section{Method}

\section{Participants}

A total of 280 faculty members and 1,044 Bachelor's students from nine Spanish universities participated in this study (see Table 1). They came from degree programmes in four fields of knowledge (arts and humanities, social and legal sciences, health sciences and engineering and architecture) (see Table 2). Of the faculty, $47.5 \%$ were male and $52.5 \%$ female, while of the students, $20 \%$ were male and $80 \%$ female. Regarding the faculty's degrees, $44.6 \%$ held Bachelor's degrees while $55.4 \%$ held doctorates. As for their teaching experience, $15.2 \%$ had

Table 1. Faculty and students at the different universities.

\begin{tabular}{lccrr}
\hline University & $N$ & $\%$ & $N$ & $\%$ \\
\hline Deusto & 57 & 20.4 & 127 & 12.2 \\
Ramón Llull & 70 & 25 & 412 & 39.5 \\
Murcia & 35 & 12.5 & 229 & 21.9 \\
Lleida & 51 & 18.2 & 19 & 1.8 \\
Pompeu Fabra & 11 & 3.9 & 5 & 0.5 \\
Alcalá & 4 & 1.4 & 68 & 6.5 \\
Autónoma de Madrid & 21 & 7.5 & 131 & 12.5 \\
Barcelona & 29 & 10.4 & 23 & 2.2 \\
Comillas & 0 & 0 & 30 & 2.9 \\
Total & 278 & 99.3 & 1,044 & 100 \\
Lost cases & 2 & 0.7 & 0 & 0 \\
Total & 280 & 100 & 1,044 & 100 \\
\hline
\end{tabular}

Table 2. Faculty and students in the different fields of knowledge.

\begin{tabular}{lrrrr}
\hline Fields of knowledge & $N$ & $\%$ & $N$ & $\%$ \\
\hline Arts and humanities & 41 & 14.6 & 30 & 2.9 \\
Social and Legal sciences & 189 & 67.5 & 703 & 67.3 \\
Health sciences & 19 & 6.8 & 286 & 27.4 \\
Engineering and architecture & 30 & 10.7 & 25 & 2.4 \\
Total & 279 & 99.6 & 1,044 & 100 \\
Lost cases & 1 & 0.4 & 0 & 0 \\
Total & 280 & 100 & 1,044 & 100 \\
\hline
\end{tabular}


between zero and four years of experience, $17.3 \%$ had between five and nine years, $16.6 \%$ had between 10 and 14 years and $50.9 \%$ had 15 years of experience or more. Regarding the students, $42 \%$ had been at the university for one or two years, $44 \%$ had been there for three or four years and $14.1 \%$ had been at the university five years or more. The native language of $54.1 \%$ of the faculty was Spanish, for $39.1 \%$ it was Catalan and for $2.2 \%$ it was Basque, while the remaining $4.6 \%$ had other native languages. Regarding the students, Spanish was the native language of $70.9 \%$, Catalan of $24.9 \%$ and Basque of $1.7 \%$, while the remaining $2.5 \%$ had other native languages.

\section{Materials}

\section{European writing survey (EUWRIT)}

We used the Spanish version of the European Writing Survey (Encuesta Europea sobre la Escritura Académica; EEEA) for both faculty and students (Chitez et al., 2015; Kruse, 2013; Kruse \& Chitez, 2012). An early version of the survey was translated ${ }^{3}$ and piloted in a previous study (Castelló, Mateos et al., 2012). Based on the results of this pilot study, the survey was revised and some items were modified in order to make them more understandable. There is a version for students and another for faculty which contain 10 and eight dimensions, respectively, which are in turn made up of 13 and 10 scales (see Table 3) with parallel items on the scales that appear in both versions. All of the scales have five possible responses on a Likert-type scale except the one on genres, which combines the Likert format with two open-ended questions on the genres that students write in at the university and a description of these genres ${ }^{4}$.

In addition to the first dimension, which gathers the personal information of the participants (age, gender, years of study/teaching, kind of studies/degree, university and native language), the dimensions and scales were designed with the intention of analysing the variables involved in writing practices (scales 2-6) and those related to values, beliefs and conceptions about the composition process and written texts (scale 5 - open-ended questions - and scale 7). The inclusion of these two major groups of variables is based on previous studies which confirm their influence when describing different written academic cultures (Chitez \& Kruse, 2012; Chitez et al., 2015; Delcambre \& Donahue, 2012; Kruse, 2013). Regarding practices, the items refer to aspects related to the amount of time spent writing, the amount and frequency of writing, instructions on both planning and writing or revising, and kind of feedback and the most frequent kinds of genres that students write. Regarding values, beliefs and conceptions, the questions encompass everything from what planning, writing and revising mean, to the values and beliefs associated with specific genres and some of their characteristics. The survey ends with two more scales, one on the existence of writing practices in a foreign language (English for countries where a different language is spoken) and another prospective scale, which aims to analyse the kinds of support students would like to receive when they write. 
Table 3. Dimensions and scales in the European survey of academic writing for students and faculty.

\begin{tabular}{|c|c|c|c|c|}
\hline & Student scales & $\begin{array}{l}\text { Cronbach's } \\
\text { alpha }\end{array}$ & Faculty scales & $\begin{array}{l}\text { Cronbach's } \\
\text { alpha }\end{array}$ \\
\hline 1 & Personal information & & Personal information & \\
\hline 2 & Writing in the curriculum & & Writing in the curriculum & \\
\hline 2.1 . & $\begin{array}{l}\text { Frequency and amount of } \\
\text { writing }\end{array}$ & .727 & $\begin{array}{l}\text { Frequency and amount of } \\
\text { writing }\end{array}$ & .668 \\
\hline 2.2 & Classroom writing practice & .702 & Classroom writing practice & .737 \\
\hline 3 & The writing process & & The writing process & \\
\hline 3.1 . & The composition process & .736 & The composition process & .714 \\
\hline 3.2 & $\begin{array}{l}\text { Characteristics of the } \\
\text { process }\end{array}$ & .766 & $\begin{array}{l}\text { Characteristics of the } \\
\text { process }\end{array}$ & \\
\hline 4 & $\begin{array}{l}\text { Frequency and kind of } \\
\text { feedback }\end{array}$ & .703 & & \\
\hline 5 & Academic genres & .857 & Academic genres & .786 \\
\hline 6 & $\begin{array}{l}\text { Mastery of academic } \\
\text { writing skills }\end{array}$ & & $\begin{array}{l}\text { Mastery of academic } \\
\text { writing skills }\end{array}$ & \\
\hline 6.1 & $\begin{array}{l}\text { Referring to the } \\
\text { composition process }\end{array}$ & .844 & $\begin{array}{l}\text { Referring to the } \\
\text { composition process }\end{array}$ & .844 \\
\hline 6.2 . & $\begin{array}{l}\text { Referring to the } \\
\text { management of } \\
\text { discursive mechanisms }\end{array}$ & .876 & $\begin{array}{l}\text { Referring to the } \\
\text { management of } \\
\text { discursive mechanisms }\end{array}$ & .820 \\
\hline 7 & $\begin{array}{l}\text { Conceptions/values/beliefs } \\
\text { about academic writing } \\
\text { ('writing well') }\end{array}$ & & $\begin{array}{l}\text { Conceptions/values/beliefs } \\
\text { about academic writing } \\
\text { ('writing well') }\end{array}$ & \\
\hline 7.1. & $\begin{array}{l}\text { Related to discursive } \\
\text { mechanisms }\end{array}$ & .626 & $\begin{array}{l}\text { Related to discursive } \\
\text { mechanisms }\end{array}$ & .549 \\
\hline 7.2 . & Related to content & .753 & Related to content & .737 \\
\hline 8 & Academic skills & .783 & Academic skills & .819 \\
\hline 9 & $\begin{array}{l}\text { Writing in a foreign } \\
\text { language (English) }\end{array}$ & .250 & $\begin{array}{l}\text { Writing in a foreign } \\
\text { language (English) }\end{array}$ & .627 \\
\hline 10 & $\begin{array}{l}\text { Prospective. Support for } \\
\text { writing }\end{array}$ & .748 & & \\
\hline
\end{tabular}

The alphas obtained for each scale (see Table 3) show acceptable reliability indexes except in the case of writing in a foreign language, so these data were not analysed in this special issue. In order to clarify the variables being analysed in each study, a precise description of the items included on each scale can be found in the articles in this special issue. The Appendix contains both versions of the complete questionnaire.

\section{Procedure}

The initial contact was made with the deans, coordinators and/or vice rectors of each university, who had to authorize us to send out a mass mailing of the survey. Having received this authorization, in accordance with the regulations and protocols in each case, we decided to create a web link to access and send the survey 
online. All the participants received the same message asking them to participate, they were informed of the purpose of the research and they provided their consent to participate before accessing the survey. The link remained active between 18 February and 22 March 2013.

The responses were gathered into the same database, which is generated by the software used for the survey ${ }^{5}$. This database was reviewed daily and the data were exported weekly, first to an Excel file for codification and later to the SPSS (v. 21) database for statistical analysis.

The information from the open-ended questions was analysed following a mixed categorization process outlined in one of the articles in this special issue (see Corcelles, Oliva, Castelló, \& Milian, 2015), which presents the data on the students' and faculty's representations of the genres they write or assign.

\section{Results}

The first result indicates that all the scales, both student and faculty, reflect a degree of agreement very close to or above 3, which means that, generally speaking, both groups positively rate the academic writing practices and competences at the university (see descriptive statistics in Tables 4 and 5).Among

Table 4. Descriptive statistics of the scales on the student questionnaire.

\begin{tabular}{lccc}
\hline & $N$ & Mean & $S D$ \\
\hline Amount of writing & 1,044 & 3.7875 & 0.82689 \\
Classroom writing practice & 1,044 & 3.0547 & 0.59189 \\
Characteristics of the process & 1,044 & 3.9366 & 0.65608 \\
Writing process & 1,044 & 3.2761 & 0.53018 \\
Frequency and kind of feedback & 1,043 & 2.8985 & 0.64249 \\
Process skills & 1,030 & 3.6090 & 0.62576 \\
Discourse skills & 1,030 & 3.6128 & 0.60869 \\
Discursive resources skills & 1,028 & 3.6673 & 0.59416 \\
Conceptions of content & 1,028 & 4.0934 & 0.60281 \\
Academic skills & 1,030 & 3.9037 & 0.57261 \\
Support for writing & 1,035 & 4.0466 & 0.58521 \\
\hline
\end{tabular}

Table 5. Descriptive statistics of the scales on the faculty questionnaire.

\begin{tabular}{lccc}
\hline & $N$ & Mean & $S D$ \\
\hline Amount of writing & 279 & 3.3250 & 0.77021 \\
Classroom writing practice & 279 & 3.4998 & 0.66218 \\
Writing process & 279 & 3.1112 & 0.62854 \\
Process skills & 277 & 3.6774 & 0.69588 \\
Discourse skills & 277 & 3.9425 & 0.55889 \\
Discursive resources skills & 276 & 3.5819 & 0.56294 \\
Conceptions of content & 276 & 4.2689 & 0.51113 \\
Students' academic skills & 273 & 3.1568 & 0.70000 \\
\hline
\end{tabular}


students, the lowest degree of agreement came in relation to the scale on the frequency with which students receive feedback on their written assignments and the kind of feedback they tend to receive (mean score of 2.9) and on the writing practices in the classroom, that is, the frequency with which they receive instructions, discuss writing and are guided when writing (mean score of 3). As can be seen, both scales are related to the help students receive with academic writing. Even though they receive little help, they state that they are asked to write quite frequently (3.8). In coherence with this, they believe that receiving more help writing in the guise of courses, feedback, tutorials, classes or online support would be useful (4). Likewise, even though they think that the characteristics of the writing process are important (3.9), they do not think that process-oriented writing activities are always done (3.3). Regarding their representation of what it means to write well, they believe that aspects related to content (objectivity, creativity, argumentation, organization, critical thinking, justification from scholarly sources) are important (4.1), but they deem aspects related to discursive mechanisms only relatively important (3.7). Finally, they feel more secure in the domain of the academic skills (3.9) than in academic writing, in terms of both the process (3.6) and the management of the discursive mechanisms common to the academic genres (3.7).

Among the faculty, the lowest degree of agreement can be found in the scale on the degree to which they believe that students engage in process-oriented writing (3.1). Likewise, they rate their students' academic skills as average (3.1). They also rate competences related to managing the discursive mechanisms of academic writing when students have to write (3.9) and aspects related to content (4.3) as important. In contrast, in their representation of what it means to write well in their field of study, they consider process-related academic writing competences (3.7) and aspects related to discursive mechanisms (3.6) less important. However, they do acknowledge that the frequency with which they ask their students to write is not high (3.3) and that they only occasionally do classroom practices to support students in their writing (3.5).

Generally speaking, according to the results of the analyses of variance performed, the differences between faculty and students on the different scales explored by the surveys were statistically significant but showed a very small effect size. The only significant difference with a noticeable effect size is related to students' and faculty's rating of the former's academic skills (3.9 and 3.1, respectively), $F=356.83, p<.001, \eta^{2}=.201$.

\section{Differences in responses according to the characteristics of both groups}

With the goal of analysing the differences between students and faculty in their representations of academic writing, one-factor ANOVAs were performed with the variables gender, native language, area of knowledge and years of experience for each of the scales on the survey. The Brown-Forsythe statistic was applied, which is a robust alternative to the $F$ statistic of the ANOVA in comparisons where we cannot assume the equality of variances. Likewise, when performing 
post-hoc analyses, we chose the Bonferroni method in contrasts in which we could assume the equality of variances, and the Games-Howell method when we could not assume this supposition.

With regard to gender, women stated that they wrote more frequently than men, $(F(1,1042)=6.145, p=.013)$, did more classroom practices, $(F(1,1042)=9.866$, $p=.002)$, considered the characteristics of the process in their writing more important, $(F(1,1042)=81.415, p=.001)$ and engaged more in process-oriented writing activities $(F(1,1042)=29.174, p=.1)$.

Regarding native language, the Spanish-speaking students expressed that they are less secure with their ability to handle the discursive mechanisms common to the academic genres than the Catalan speakers $(F(3,1026)=3.358, p=.018)$, and less secure in their mastery of the academic skills than the speakers of other languages $(F(3,1026)=4.420, p=.004)$. In contrast, in their representations of what it means to write well, the Spanish-speaking students valued aspects related to content $(F(3,1024)=5.081, p=.002)$ and discursive mechanisms more highly than the Catalan speakers $(F(3,1024)=5.214, p=.001)$.

The variable in which we noted the greatest differences was the area of knowledge. What is more, almost all of these differences trend in the same direction. The students of the arts and humanities and the social and legal sciences declared that they write more (Brown-Forsythe $(3,71.414)=20.324$, $p=.001)$, do more writing practice in the classroom $(F(3,1040)=10.747$, $p=.001)$, do more process-oriented writing activities $(F(3,1040)=9.202$, $p=.001)$ and receive more feedback than their peers in the health sciences and engineering and architecture $(F(3,1039)=12.939, p=.001)$. The students in the health sciences mentioned more classroom writing practices and more activities aimed at process writing than the students in engineering and architecture. Likewise, the students in the arts and humanities, the social and legal sciences, and the health sciences believed that the characteristics of the process in their writing is more important $(F(3,1040)=5.045, p=.002)$, and they stated that support for writing would be useful $(F(3,1031)=11.572, p=.001)$ more often than engineering and architecture students. The students in the social sciences stated that they felt more secure with their academic skills than the students in the health sciences $(F(3,1026)=4.989, p=.002)$. Finally, in their representations of what it means to write well, the students in engineering and architecture placed more value on aspects related to the discursive mechanisms than the students in the health sciences (BrownForsythe $(3,108.338)=2.736, p=.047)$.

The number of years of experience at the university also affected some of the dimensions of academic writing. Specifically, students with one or two years of experience stated that they did more writing practice in the classroom $(F(2,1041)=21.311, p=.001)$ and more process-oriented activities $(F(2,1041)=21.571, p=.001)$, and that they received more feedback $(F(2,1040)=9.453, p=.001)$, than those with more years of experience. In turn, students with three or four years of experience stated that they write more (Brown-Forsythe $(2,572.862)=3.909, p=.021)$, do more writing practice in 
the classroom and receive more feedback than students with five or more years of experience.

In the case of faculty, the area of knowledge in which they teach is also the variable that explains the most differences, and it shows the same trends as in the students. Faculty in the arts and humanities and the social and legal sciences stated that they ask their students to write more frequently $(F(3,274)=9.681$, $p=.001)$ and do more writing practice in the classroom $(F(3,274)=7.532$, $p=.001)$ than faculty in engineering and architecture. Furthermore, when students have to write, faculty in the arts and humanities, the social and legal sciences, and the health sciences believe that academic writing skills related to process-writing are more important (Brown-Forsythe $(3,77.368)=9.443, p=.001)$, as is managing discursive mechanisms (Brown-Forsythe $(3,87.360)=6.682, p=.001$ ), and they place a higher value on aspects related to content than faculty in engineering and architecture $(F(3,271)=8.557, p=.001)$.

Regarding the native language, the Spanish-speaking and Catalan-speaking faculty stated that students engage in process-oriented writing activities more than the faculty who speak other languages $(F(3,275)=3.616, p=.014)$. Finally, we found no significant differences in the variables analysed related to gender and the number of years teaching.

\section{Discussion and conclusions}

In this first article of the special issue, we have striven to present the characteristics, underpinnings and structure of the European Writing Survey (EUWRIT) (in its Spanish version: Encuesta Europea sobre la Escritura Académica; EEEA) and to describe the general representations of academic writing among faculty and students while relating them to the characteristics of the participants, disciplines and educational levels.

With regard to the two versions of the EUWRIT (in its Spanish version: EEEA), we should stress that the results in the Spanish sample showed acceptable reliability indicators on the majority of scales, making it a useful instrument for describing the perceptions of those involved in relation to the status of writing in the context of university teaching and learning. Furthermore, none of the participants indicated that they had any specific difficulty filling out the survey. The fact that several scales are the same in both versions also enables us to readily check the perceptions of faculty and students on the majority of aspects analysed.

The results on the representations and their relations with the characteristics of the participants indicate that they differ in relation to the disciplinary field more than the other variables analysed (gender, native language and level of experience). Both faculty and students in the arts and humanities and the social sciences believe that they write more, are more process-oriented and receive or give more feedback than their counterparts in the other areas of knowledge in our sample. These results confirm what has been found in other previous studies in our milieu (Castelló, Mateos et al., 2012; Mateos et al., 2007), as well as in different milieus (Chitez \& Kruse, 2012; Natale, 2012; Pérez-Abril \& Rodríguez, 2013). It is somewhat more 
surprising that this output does not rise as students progress through university, which does contrast with recent results from other countries (Delcambre \& Donahue, 2012). Another surprising find is the congruence between the faculty and student representations in terms of both practices and skills, a controversial topic in current research (Bazerman et al., 2012). In the ensuing articles in this special issue, we further explore these relationships and provide further detail on some of the general descriptions noted in this paper, which will enable us to more precisely analyse the status of writing at Spanish universities, a necessary step before being able to optimize it.

We are aware of the limitations of this study, which are largely due to its initial, exploratory nature. First, the participants responded voluntarily and were limited to a restricted spectrum of degree programmes and universities; therefore, this is not a representative sample. Secondly, the data gathered are based on a single survey; although it is an efficient, useful instrument for our purposes, it only reports what the participants claim, not necessarily what truly happens in university classrooms. However, the large number of participants, especially students, and their distribution around different geographic areas within Spain, as well as their attendance at different kinds of universities, mean that the results are relevant and that the trends and analyses discussed in the different articles of this special issue can serve as a preliminary general X-ray of the current status of writing in Spain. Obviously, however, this must be further explored with subsequent studies that precisely outline differences by specific groups and ensure their representativeness in these groups. And, indeed, some of these studies are already underway within the Network.

\section{Notes}

1. European Research Network on Learning to Write Effectively (ERN-LWE). COST Action IS0703.

2. The RIEA-EA was created in June 2012 with the goal of sharing knowledge, generating coordination mechanisms and analysing the state of the matter in Spanish research into academic writing in higher education (see the presentation of this special issue for more information).

3. The survey was translated following the back-translation method (BTM) with the participation of researchers who were native speakers of both languages in each stage in the process.

4. Appendix 1 of this article contains both versions of the complete survey.

5. This is a free software programme used to develop forms provided by Google. 


\section{Las representaciones de profesores y estudiantes sobre la escri- tura académica en las universidades españolas}

El estudio de la escritura académica ha generado en los últimos 20 años un ingente número de publicaciones y ha sido el centro de interés de seminarios y conferencias de alcance internacional (Bazerman et al., 2012). Sin embargo, el conocimiento de las prácticas y concepciones y, en definitiva, del estatus que la escritura tiene en la Educación Superior es muy diferente según los contextos y las tradiciones.

En el contexto anglosajón, fundamentalmente en países de habla inglesa, como los EEUU o el Reino Unido, la enseñanza de la escritura y el análisis de las prácticas que la caracterizan en la universidad ha sido un tema de gran relevancia a lo largo de todo el siglo XX, con un crecimiento exponencial a lo largo de los últimos 50 años, por lo que su influencia en la investigación actual es innegable (Bazerman et al., 2005). El alegato pionero de Britton (1970), acerca de la necesidad de que los estudiantes escribieran textos funcionales en el seno de las disciplinas, así como su reivindicación del poder epistémico de la escritura, lo sitúan como precursor de los movimientos Writing Accross Curriculum (WAC) y Writing in the Disciplines (WID) en los EEUU y del enfoque denominado Academic Literacies (ACLITS) en el Reino Unido (Russell, Lea, Parker, Street, \& Donahue, 2009). Este objetivo complejo y ambicioso ha generado dos grandes líneas de investigación: (a) la que se ocupa de estudiar los textos y los discursos de una determinada disciplina; y (b) la que se interroga, como en nuestro caso, por las prácticas y los textos que se escriben en las aulas universitarias (Bazerman, 1992; Russell, 1991, 1997). Los resultados de la primera línea de investigación han permitido caracterizar las particularidades y funciones del discurso en múltiples disciplinas (Hyland, 2005) y géneros científicos (Hyland, 2008; Swales, 2004) o académicos (Gardner \& Nesi, 2013) que, además, han dado lugar a múltiples propuestas formativas (Bazerman, Bonini, \& Figueiredo, 2009). También en esta primera línea se han explorado las concepciones de los estudiantes sobre los procesos de composición, ya sea desde perspectivas fenomenográficas (Lavelle \& Zuercher, 2001) o desde las teorías implícitas (White \& Bruning, 2005). En el primer caso, los resultados remiten a dos enfoques de escritura opuestos, que se corresponden, a grandes rasgos, con los modelos de decir o transformar el conocimiento caracterizados en su día por Bereiter y Scardamalia (1987). Por su parte, White y Brunning (2005) identificaron la existencia de creencias transmisivas y transaccionales; estas últimas se vinculan con una mayor implicación cognitiva y afectiva en la escritura, mejores niveles de organización textual, de desarrollo de las ideas y de calidad general del escrito. 
La segunda línea de investigación integra desde estudios a gran escala, en los que se analizan y revisan las prácticas nacionales, tanto de enseñanza (Applebee \& Langer, 2013) como de evaluación de la escritura (Applebee, 2013), hasta estudios de corte cualitativo y etnográfico que evalúan los rasgos diferenciales de estas prácticas y sus resultados (Carroll, 2002; Walvoord \& McCarthy, 2008). Algunos trabajos en esta línea, desarrollados en el Reino Unido desde el movimiento ACLITS, han permitido, además, poner de manifiesto los múltiples discursos que compiten en el contexto académico y enfatizar los mecanismos que llevan a profesores y estudiantes a priorizar unos por encima de otros (Ivanič, 1998; Lea, 2012; Lillis, 1997).

El estudio de Lea y Street (1998) supuso un punto de inflexión al enfatizar la necesidad de tener en cuenta las expectativas y la forma en que interpretan la escritura docentes y estudiantes. Sus resultados indican la existencia de tres grandes modelos que explican las concepciones, a menudo implícitas, y prácticas asociadas a la enseñanza de la escritura. El primero, centrado en las técnicas o habilidades de estudio (study skills), asocia el desarrollo de la competencia de los estudiantes en la escritura académica al dominio de la gramática, sintaxis, ortografía y puntuación. El segundo, enfatiza la socialización académica (socialisation), la familiarización de los estudiantes con los discursos y géneros de las disciplinas para participar de la cultura de las mismas. El tercer modelo, engloba los anteriores y persigue la alfabetización(es) académica(s) (academic literacy/ies), de tal manera que exige además tener en cuenta la naturaleza de las prácticas institucionales, las relaciones de poder y su impacto en las identidades de estudiantes y profesores. Esta última concepción ha permitido, en los últimos años, caracterizar la emergencia de nuevas prácticas y contextos de escritura que exigen repensar su enseñanza y tratamiento (Lea, 2012; Lea \& Stierer, 2000; Robinson-Pant \& Street, 2012). En esta línea se sitúan los estudios que también han analizado la interacción entre las prácticas de escritura que predominan en las aulas universitarias con el desarrollo de sus identidades y el posicionamiento de estudiantes y profesionales (Casanave \& Vandrick, 2003; Ivanič, 1998).

En el resto de países europeos de habla no inglesa, los estudios sobre las concepciones de escritura, sobre todo a gran escala, aparecen más recientemente y son menos frecuentes. Además, la diversidad lingüística, cultural y de prácticas asociadas a la Educación Superior contribuyen a una cierta dispersión del conocimiento en este ámbito. Aun así, son relevantes los trabajos sobre concepciones acerca de la naturaleza de la escritura que la asocian a elevados niveles de estrés, especialmente en el postgrado y doctorado (Lonka et al., 2014), o los trabajos centrados en cómo la enseñanza en contextos multivocales influye en las actitudes y concepciones de los estudiantes y en el uso epistémico de la escritura (Dysthe, 2012). También el tema de los desencuentros a nivel de representaciones y expectativas entre profesores y estudiantes ha sido recurrente en la investigación europea sobre las prácticas de escritura. Los resultados de estos estudios muestran cambios en estas representaciones a medida que los estudiantes progresan hacia niveles superiores en sus estudios, que están además mediados por determinadas 
prácticas disciplinares (Delcambre \& Donahue, 2012) y por los cambios institucionales que rodean a la Educación Superior (Robinson-Pant \& Street, 2012).

En los últimos años, el interés de los investigadores por traspasar fronteras, tanto lingüísticas como geográficas y culturales, ha permitido la aparición de iniciativas y publicaciones que, además de propiciar el diálogo entre tradiciones diversas, han permitido sentar las bases de proyectos transculturales de alcance internacional, especialmente en el ámbito de la escritura académica (Castelló \& Donahue, 2012). Una de estas iniciativas fue el proyecto Learning to Write Effectively (ERN-LWE) ${ }^{1}$ que conectó investigadores de 23 países europeos. Entre sus resultados está el desarrollo de la Encuesta Europea sobre la Escritura Académica (EEEA) (en su versión inglesa: European Writing Survey; EUWRIT), que tiene dos versiones una para estudiantes y otra para profesores, disponible actualmente en ocho idiomas, entre ellos español, catalán y euskera, y utilizado como principal fuente de recogida de datos en los artículos de este monográfico (Chitez, Kruse, \& Castelló, 2015; Kruse, 2013; Kruse \& Chitez, 2012).

También en España, y en los países latinoamericanos, ha aumentado de forma clara el interés y las publicaciones que se ocupan de la situación de la escritura académica (Camps \& Castelló, 2013), así como las propuestas de enseñanza de los géneros que se escriben en las diferentes disciplinas y niveles de formación universitarios (Álvarez-Angulo, 1996; Castello, 2007; Castelló, 2009; Perea, 2013; Solé, Teberosky, \& Castelló, 2012; Tolchinsky, 2013). Recientemente, también se han desarrollado instrumentos de análisis de las concepciones y actitudes de los estudiantes sobre la escritura (Álvarez, Villardón, \& Yániz, 2010; Villalón \& Mateos, 2009) y se ha indagado sobre actividades y géneros específicos como la síntesis y la argumentación (Álvarez, Villardón, \& Yániz, 2008; Mateos \& Solé, 2009; Mateos et al., 2014) y sus relaciones con la adquisición de conocimiento (Mateos, Villalón, de Dios, \& Martín, 2007; Mateos et al., 2011; Solé et al., 2005). En líneas generales, los resultados ponen de manifiesto las dificultades de los estudiantes y la ausencia de tareas de escritura epistémica en la educación superior. Paralelamente, se han diseñado y analizado propuestas formativas para facilitar a los estudiantes la apropiación de géneros específicos vinculados a la profesionalización del estudiante (Roca de Larios \& Serrano, 2011) o a la investigación como la escritura de las tesis de grado (Castelló, Inesta, Pardo, Liesa, \& Martínez-Fernández, 2012; Corcelles, Cano, Bañales, \& Vega, 2013) y de artículos de investigación (Castelló, Iñesta, \& Corcelles, 2013). Los resultados de estos trabajos recientes apuntan al desarrollo de comunidades de aprendizaje en las que los estudiantes puedan regular y superar estas tensiones y desarrollar su identidad como escritores (Iñesta \& Castelló, 2012; Oliva \& Milian, 2013).

A pesar de estos y otros avances sin duda remarcables, la compartimentación de la universidad española, basada en las áreas disciplinares y la existencia de medios de difusión que también están fuertemente sectorizados, hace difícil el conocimiento e integración de las diferentes iniciativas. A esta dispersión se une el hecho de que no disponemos de estudios de largo alcance que describan el estatus de la escritura en las universidades españolas. Exceptuando algunos casos 
aislados (Castelló, Mateos et al., 2012; Mateos et al., 2007; Perea, 2013; Solé et al., 2005), sabemos todavía muy poco de cuándo y por qué escriben nuestros estudiantes en diferentes disciplinas, si se les ayuda a gestionar el proceso de composición o sólo se evalúan los textos finales o si profesores y estudiantes entienden lo mismo cuando solicitan un informe, un resumen o la resolución de un caso por escrito. Con el objetivo de avanzar en este conocimiento, en el marco de la Red para la Investigación de la Enseñanza y el Aprendizaje de la Escritura Académica (RIEA-EA) ${ }^{2}$, hemos desarrollado los estudios incluidos en este monográfico que supone una primera aproximación a cómo estudiantes y profesores describen sus prácticas habituales de escritura y cuáles son las concepciones que sustentan estas prácticas en diferentes contextos disciplinares.

En este primer artículo, que enmarca el monográfico, presentaremos las características, fundamentación y estructura del instrumento utilizado y nos ocuparemos de describir las representaciones generales sobre la escritura académica de profesores y estudiantes relacionándolas con las características de los participantes, disciplinas y niveles educativos.

\section{Método}

\section{Participantes}

Participaron en el estudio un total de 280 profesores/as y de 1,044 estudiantes de grado de nueve universidades españolas (ver Tabla 1) procedentes de titulaciones de cuatro campos de conocimiento (artes y humanidades, ciencias sociales y jurídicas, ciencias de la salud e ingeniería y arquitectura) (ver Tabla 2). Del total del profesorado, el $47.5 \%$ eran hombres y el 52.5\% mujeres. En el caso de los estudiantes, el $20 \%$ eran hombres y el $80 \%$ mujeres. Por lo que respecta a la titulación del profesorado, el $44.6 \%$ eran licenciados/as y el 55.4\% eran doctores/ as. En relación con la experiencia docente, el $15.2 \%$ tenían entre cero y cuatro años de experiencia, el $17.3 \%$, entre cinco y nueve, el $16.6 \%$, entre 10 y 14 y el

Tabla 1. Profesores y estudiantes en las diferentes universidades.

\begin{tabular}{lccrr}
\hline Universidad & $N$ & $\%$ & $N$ & $\%$ \\
\hline Deusto & 57 & 20.4 & 127 & 12.2 \\
Ramón Llull & 70 & 25 & 412 & 39.5 \\
Murcia & 35 & 12.5 & 229 & 21.9 \\
Lleida & 51 & 18.2 & 19 & 1.8 \\
Pompeu Fabra & 11 & 3.9 & 5 & 0.5 \\
Alcalá & 4 & 1.4 & 68 & 6.5 \\
Autónoma de Madrid & 21 & 7.5 & 131 & 12.5 \\
Barcelona & 29 & 10.4 & 23 & 2.2 \\
Comillas & 0 & 0 & 30 & 2.9 \\
Total & 278 & 99.3 & 1,044 & 100 \\
Casos perdidos & 2 & 0.7 & 0 & 0 \\
Total & 280 & 100 & 1,044 & 100 \\
\hline
\end{tabular}


Tabla 2. Profesores y estudiantes en los diferentes campos de conocimiento.

\begin{tabular}{lrrrr}
\hline Campos de conocimiento & $N$ & $\%$ & $N$ & $\%$ \\
\hline Artes y humanidades & 41 & 14.6 & 30 & 2.9 \\
Ciencias sociales y jurídicas & 189 & 67.5 & 703 & 67.3 \\
Ciencias de la salud & 19 & 6.8 & 286 & 27.4 \\
Ingeniería y arquitectura & 30 & 10.7 & 25 & 2.4 \\
Total & 279 & 99.6 & 1,044 & 100 \\
Casos perdidos & 1 & 0.4 & 0 & 0 \\
Total & 280 & 100 & 1,044 & 100 \\
\hline
\end{tabular}

$50.9 \%, 15$ años o más. En el caso de los/las estudiantes, el $42 \%$ tenían uno o dos años de experiencia universitaria, el $44 \%$, tres ó cuatro, y el $14.1 \%$, cinco ó más. La lengua materna en la muestra de profesores/as era el castellano en el $54.1 \%$ de los casos, el catalán en el $39.1 \%$, el euskera en el $2.2 \%$ y otras lenguas en el $4.6 \%$ de los casos restantes. En el caso de los/las estudiantes, la lengua materna era el castellano en el $70.9 \%$ de los casos, el catalán en el $24.9 \%$, el euskera en el $1.7 \%$ y otras lenguas en el $2.5 \%$ restante.

\section{Materiales}

\section{Encuesta Europea sobre la escritura Académica (EEEA)}

Se utilizó la versión en español del European Writing Survey (EUWRIT), para profesores y estudiantes (Chitez et al., 2015; Kruse, 2013; Kruse \& Chitez, 2012). Una primera versión del cuestionario fue traducida ${ }^{3}$ y pilotada en un estudio anterior (Castelló, Mateos et al., 2012). En base a los resultados de este estudio piloto, el cuestionario fue revisado y algunos ítems modificados para mejorar su comprensión. Consta de una versión para estudiantes y otra para profesores de 10 y ocho dimensiones respectivamente que, a su vez, incluyen 13 y 10 escalas (ver Tabla 3), con ítems paralelos en aquellas escalas que aparecen en ambas versiones. Todas las escalas tienen cinco opciones de respuesta tipo Likert, excepto la de géneros que combina este formato con dos preguntas abiertas relativas a los géneros que los estudiantes escriben en la universidad y su descripción ${ }^{4}$.

Aparte de una primera dimensión en la que se recogen los datos personales de los participantes (edad, género, años de estudio/docencia, tipo de estudios/ titulación, universidad y lengua materna), las dimensiones y escalas se diseñaron con la intención de analizar las variables involucradas en las prácticas de escritura (escalas 2-6) y aquellas relativas a los valores, creencias y concepciones sobre el proceso de composición y los textos escritos (escala 5 - preguntas abiertas - y 7). La inclusión de estos dos grandes grupos de variables se fundamenta en los estudios previos que avalan su influencia en la caracterización de diferentes culturas académicas escritas (Chitez \& Kruse, 2012; Delcambre \& Donahue, 2012; Kruse, 2013). En cuanto a las prácticas, los ítems se refieren a aquellos aspectos relativos al tiempo dedicado a la escritura, cantidad y frecuencia de la misma, instrucciones tanto para planificar como para escribir o revisar, tipo 
Tabla 3. Dimensiones y escalas de la Encuesta Europea sobre escritura para estudiantes y profesores.

\begin{tabular}{|c|c|c|c|c|}
\hline & Escalas estudiantes & $\begin{array}{l}\text { Alfa de } \\
\text { Cronbach }\end{array}$ & Escalas profesores & $\begin{array}{l}\text { Alfa de } \\
\text { Cronbach }\end{array}$ \\
\hline 1 & Datos personales & & Datos personales & \\
\hline 2 & La escritura en el currículo & & La escritura en el currículo & \\
\hline 2.1 . & $\begin{array}{l}\text { Frecuencia y cantidad de } \\
\text { escritura }\end{array}$ & .727 & $\begin{array}{l}\text { Frecuencia y cantidad de } \\
\text { escritura }\end{array}$ & .668 \\
\hline 2.2 . & Prácticas de escritura/aula & .702 & Prácticas de escritura/aula & .737 \\
\hline 3 & El proceso de escritura & & El proceso de escritura & \\
\hline 3.1 . & El proceso de composición & .736 & El proceso de composición & .714 \\
\hline 3.2 . & Características del proceso & .766 & Características del proceso & \\
\hline 4 & $\begin{array}{l}\text { Frecuencia y tipo de } \\
\text { feed-back }\end{array}$ & .703 & & \\
\hline 5 & Géneros académicos & .857 & Géneros académicos & .786 \\
\hline 6 & $\begin{array}{l}\text { Dominio de competencias de } \\
\text { escritura académica }\end{array}$ & & $\begin{array}{l}\text { Dominio de competencias de } \\
\text { escritura académica }\end{array}$ & \\
\hline 6.1 . & $\begin{array}{l}\text { Referidas al proceso de } \\
\text { composición }\end{array}$ & .844 & $\begin{array}{l}\text { Referidas al proceso de } \\
\text { composición }\end{array}$ & .844 \\
\hline 6.2 . & $\begin{array}{l}\text { Referidas a la gestión de los } \\
\text { mecanismos discursivos }\end{array}$ & .876 & $\begin{array}{l}\text { Referidas a la gestión de los } \\
\text { mecanismos discursivos }\end{array}$ & .820 \\
\hline 7 & $\begin{array}{l}\text { Concepciones/valores/ } \\
\text { creencias acerca de la } \\
\text { escritura académica } \\
\text { ('escribir bien') }\end{array}$ & & $\begin{array}{l}\text { Concepciones/valores/ } \\
\text { creencias acerca de la } \\
\text { escritura académica } \\
\text { ('escribir bien') }\end{array}$ & \\
\hline 7.1. & $\begin{array}{l}\text { Relativos a los mecanismos } \\
\text { discursivos }\end{array}$ & .626 & $\begin{array}{l}\text { Relativos a los mecanismos } \\
\text { discursivos }\end{array}$ & .549 \\
\hline 7.2 . & Relativos al contenido & .753 & Relativos al contenido & .737 \\
\hline 8 & Competencias de estudio & .783 & Competencias de estudio & .819 \\
\hline 9 & $\begin{array}{l}\text { Escritura en lengua extranjera } \\
\text { (inglés) }\end{array}$ & .250 & $\begin{array}{l}\text { Escritura en lengua extranjera } \\
\text { (inglés) }\end{array}$ & .627 \\
\hline 10 & $\begin{array}{l}\text { Prospectiva. Apoyo para la } \\
\text { escritura }\end{array}$ & .748 & & \\
\hline
\end{tabular}

de feedback y tipología más frecuente de géneros que escriben los estudiantes. En relación a los valores, creencias y concepciones, las preguntas abarcan desde lo que se entiende por planificar, escribir y revisar hasta los valores y creencias asociados a géneros específicos y algunas de sus características. El cuestionario se completa con dos escalas más, una de ellas relativa a la existencia de prácticas de escritura en lengua extranjera (inglés para aquellos países con una lengua diferente) y la otra prospectiva, dirigida a analizar el tipo de apoyo que los estudiantes desearían recibir para escribir.

Las alphas obtenidas para cada una de las escalas (ver Tabla 3 ) muestran unos índices de fiabilidad aceptables excepto en el caso de la escritura en lengua extranjera, por lo que estos datos no se han analizado en este monográfico. La descripción precisa de los ítems incluidos en cada escala se realiza en los artículos de este monográfico con el objeto de clarificar las variables objeto de análisis en 
cada uno de los estudios. En el anexo se puede consultar el cuestionario completo en sus dos versiones.

\section{Procedimiento}

Se realizó un primer contacto con los decanos, coordinadores y/o vicerrectores que, en cada universidad, debían autorizar el envío masivo de los cuestionarios. Recabada esta autorización, de acuerdo a la normativa y protocolos existentes en cada caso, se decidió el sistema de envío del link de acceso a los cuestionarios online. Todos los participantes recibieron el mismo mensaje en el que se solicitaba su colaboración, se informaba de los objetivos de la investigación y, antes de acceder al cuestionario, dieron su consentimiento para participar en la misma. El link se mantuvo activo entre el 18 de febrero y el 22 de marzo de 2013.

Las respuestas se centralizaron en una misma base de datos que genera el propio software que se utilizó para el cuestionario ${ }^{5}$. Esta base de datos fue diariamente revisada y los datos exportados semanalmente, primero a un archivo Excel para su codificación, y posteriormente a la base de datos de SPSS (v. 21) para su análisis estadístico.

Los datos relativos a las preguntas abiertas fueron analizados siguiendo un proceso de categorización mixto que se detalla en uno de los artículos de este monográfico (ver al respecto Corcelles, Oliva, Castelló, \& Milian, 2015), en el que se presentan los datos relativos a las representaciones de estudiantes y profesores sobre los géneros que escriben o solicitan.

\section{Resultados}

Una primera constatación indica que, en todas las escalas, tanto los estudiantes como los profesores reflejan un grado de acuerdo muy próximo a, o por encima de, 3 lo que pone de manifiesto que, en general, ambos colectivos valoran positivamente las prácticas y competencias de escritura académica en la universidad (ver estadísticos descriptivos en las Tablas 4 y 5).

Entre los estudiantes, el menor grado de acuerdo se alcanza en relación con la escala relativa a la frecuencia con que los estudiantes reciben feedback de sus trabajos escritos y al tipo de feedback que suelen recibir (puntuación media de 2.9) y con la relativa a las prácticas de escritura que se llevan a cabo en el aula, esto es, la frecuencia con que reciben instrucciones, se discute acerca de la escritura y se guía la escritura (puntuación media de 3). Como puede observarse, ambas escalas se relacionan con las ayudas a la escritura académica. Aunque reciben pocas ayudas, declaran que se les solicita escribir con cierta frecuencia (3.8). De forma coherente, consideran que recibir más apoyos para la escritura, en forma de cursos, feedback, tutorías, clases o apoyo on-line sería útil (4). Asimismo, aunque consideran importantes las características del proceso en su escritura (3.9) no consideran que siempre realicen las actividades de escritura orientadas al proceso (3.3). En cuanto a su representación sobre lo que implica escribir bien, valoran como importantes los aspectos relativos al contenido (objetividad, creatividad, argumentación, 
Tabla 4. Estadísticos descriptivos de escalas del cuestionario de estudiantes.

\begin{tabular}{lccc}
\hline & $N$ & Media & $D T$ \\
\hline Cantidad escritura & 1,044 & 3.7875 & 0.82689 \\
Practica escritura en aula & 1,044 & 3.0547 & 0.59189 \\
Características proceso & 1,044 & 3.9366 & 0.65608 \\
Proceso de escritura & 1,044 & 3.2761 & 0.53018 \\
Frecuencia y tipo de feedback & 1,043 & 2.8985 & 0.64249 \\
Competencias proceso & 1,030 & 3.6090 & 0.62576 \\
Competencias discurso & 1,030 & 3.6128 & 0.60869 \\
Concepciones recursos discursivos & 1,028 & 3.6673 & 0.59416 \\
Concepciones contenido & 1,028 & 4.0934 & 0.60281 \\
Competencias de estudio & 1,030 & 3.9037 & 0.57261 \\
Apoyos escritura & 1,035 & 4.0466 & 0.58521 \\
\hline
\end{tabular}

Tabla 5. Estadísticos descriptivos de escalas del cuestionario de profesores.

\begin{tabular}{lccc}
\hline & $N$ & Media & $D T$ \\
\hline Cantidad escritura & 279 & 3.3250 & 0.77021 \\
Practica escritura en aula & 279 & 3.4998 & 0.66218 \\
Proceso escritura & 279 & 3.1112 & 0.62854 \\
Competencias proceso & 277 & 3.6774 & 0.69588 \\
Competencias discurso & 277 & 3.9425 & 0.55889 \\
Concepciones recursos discursivos & 276 & 3.5819 & 0.56294 \\
Concepciones contenido & 276 & 4.2689 & 0.51113 \\
Competencias estudio estudiantes & 273 & 3.1568 & 0.70000 \\
\hline
\end{tabular}

estructuración, pensamiento crítico, justificación en fuentes científicas) (4.1), pero consideran sólo relativamente importantes los aspectos relativos a los mecanismos discursivos (3.7). Por último, se sienten más seguros en el dominio de las competencias de estudio (3.9), que en las de escritura académica, tanto en las referidas al proceso (3.6) como en las referidas a la gestión de los mecanismos discursivos propios de los géneros académicos (3.7).

Entre los profesores, el menor grado de acuerdo se observa en la escala relativa al grado en que consideran que los estudiantes llevan a cabo actividades de escritura orientadas al proceso (3.1). Asimismo, atribuyen a sus estudiantes unas competencias de estudio que valoran como medias (3.1). Valoran también como importantes las competencias referidas a la gestión de los mecanismos discursivos propios de la escritura académica cuando los estudiantes tienen que escribir (3.9) y los aspectos relativos al contenido (4.3). En cambio, en su representación sobre lo que implica escribir bien en su campo de estudio, consideran menos importantes las competencias de escritura académica referidas al proceso (3.7) y los aspectos relativos a los mecanismos discursivos, (3.6). Reconocen, sin embargo, que la frecuencia con que solicitan a sus estudiantes que escriban no es alta (3.3), 
y que sólo a veces realizan prácticas en el aula dirigidas a apoyar a los estudiantes en su escritura (3.5).

En general, de acuerdo con los resultados de los análisis de varianza realizados, las diferencias entre profesores y estudiantes en las diferentes escalas exploradas por los cuestionarios, aunque estadísticamente significativas, presentan un tamaño del efecto muy pequeño. La única diferencia significativa con un tamaño del efecto apreciable es la relativa a la valoración que hacen estudiantes y profesores de las competencias de estudio de los primeros (3.9 y 3.1 respectivamente), $F=356.83, p<.001, \eta^{2}=.201$.

\section{Diferencias en las respuestas en función de las características de ambos colectivos}

Con el objetivo de analizar las diferencias entre estudiantes y profesores en sus representaciones sobre la escritura académica se realizaron ANOVAS de un factor con las variables género, lengua materna, área de conocimiento y años de experiencia para cada una de las escalas del cuestionario. Se aplicó el estadístico de BrownForsythe, que representa una alternativa robusta al estadístico $F$ del ANOVA, en aquellas comparaciones donde no se pudo asumir la igualdad de varianzas. Asimismo, al efectuar las comparaciones post-hoc, se seleccionó el método de Bonferroni en aquellos contrastes en los que se pudo asumir la igualdad de varianzas y el método de Games-Howell en los que no se pudo asumir este supuesto.

En relación con el género, las mujeres declararon escribir con más frecuencia que los hombres, $(F(1,1042)=6.145, p=.013)$, realizar más prácticas de escritura en el aula, $(F(1,1042)=9.866, p=.002)$, considerar más importantes las características del proceso en su escritura, $(F(1,1042)=81.415, p=.001)$, realizar en mayor medida las actividades de escritura orientadas al proceso $(F(1,1042)=29.174, p=.001)$ y sentirse más seguras en el dominio de las competencias de escritura académica referidas al proceso, (Brown-Forsythe $(1,288.015)=4.619, p=.032)$. Asimismo, consideraron en mayor medida que sus compañeros varones que recibir más apoyos para la escritura sería útil, (Brown-Forsythe $(1,276.575)=19.509, p=.001)$.

Por lo que respecta a la lengua materna, los estudiantes ${ }^{6}$ castellanohablantes se manifiestaron menos seguros de sus competencias de gestión de los mecanismos discursivos propios de los géneros académicos que los/las catalanohablantes $(F(3,1026)=3.358, p=.018)$, y menos seguros/as en el dominio de las competencias de estudio que los hablantes de otras lenguas $(F(3,1026)=4.420$, $p=.004)$. En cambio, en sus representaciones sobre lo que implica escribir bien, los estudiantes castellanohablantes valoraron en mayor medida que los catalanohablantes los aspectos relativos al contenido $(F(3,1024)=5.081, p=.002)$, y a los mecanismos discursivos $(F(3,1024)=5.214, p=.001)$.

La variable en la que se observaron más diferencias fue el área de conocimiento. Además, casi todas ellas se encuentran en la misma dirección. Los estudiantes de artes y humanidades y de ciencias sociales y jurídicas declararon escribir más (Brown-Forsythe $(3,71.414)=20.324, p=.001)$, realizar más 
prácticas de escritura en el aula $(F(3,1040)=10.747, p=.001)$, más actividades de escritura orientadas al proceso $(F(3,1040)=9.202, p=.001)$, y recibir más feedback que sus compañeros de ciencias de la salud y de ingeniería y arquitectura $(F(3,1039)=12.939, p=.001)$. También los estudiantes de ciencias de la salud mencionaron más prácticas de escritura en el aula y más actividades orientadas al proceso que los de ingeniería y arquitectura. Asimismo, los estudiantes de artes y humanidades, ciencias sociales y jurídicas y ciencias de la salud consideraron más importantes las características del proceso en su escritura $(F(3,1040)=5.045$, $p=.002)$, y manifestaron en mayor medida que los apoyos a la escritura serían útiles $(F(3,1031)=11.572, p=.001)$, que los de ingeniería y arquitectura. Los estudiantes de ciencias sociales afirmaron sentirse más seguros de sus competencias de estudio que los de ciencias de la salud $F(3,1026)=4.989, p=.002$. Por último, en sus representaciones sobre lo que implica escribir bien, los estudiantes de ingeniería y arquitectura valoraron en mayor medida que los de ciencias de la salud los aspectos relativos a los mecanismos discursivos (Brown-Forsythe (3, $108.338)=2.736, p=.047)$.

Los años de experiencia universitaria también afectan a algunas dimensiones de la escritura académica. Concretamente, los estudiantes con uno o dos años de experiencia declararon realizar más prácticas de escritura en el aula $(F(2,1041)=21.311, p=.001)$, más actividades orientadas al proceso $(F(2,1041)=21.571, p=.001)$, y recibir más feedback $(F(2,1040)=9.453$, $p=.001)$, que los que tienen más años de experiencia. A su vez, los estudiantes con tres o cuatro años de experiencia manifestaron escribir más (BrownForsythe $(2,572.862)=3.909, p=.021)$, realizar más prácticas de escritura en el aula, y recibir más feedback que aquellos con cinco o más años de experiencia.

En el caso de los profesores, también es la variable área de conocimiento en la que imparten docencia la que explica más diferencias y en la misma dirección que en el colectivo de estudiantes. El profesorado de artes y humanidades y de ciencias sociales y jurídicas declaró que solicitaba a sus estudiantes escribir con más frecuencia $(F(3,274)=9.681, p=.001)$, y realizar más prácticas de escritura en el aula $(F(3,274)=7.532, p=.001)$, que el de ingeniería y arquitectura. Además, los profesores de artes y humanidades, de ciencias sociales y jurídicas y de ciencias de la salud, cuando los estudiantes tienen que escribir, consideraron más importantes las competencias de escritura académica referidas tanto al proceso (Brown-Forsythe $(3,77.368)=9.443, p=.001)$, como a la gestión de los mecanismos discursivos (Brown-Forsythe $(3,87.360)=6.682, p=.001)$, y valoraron en mayor medida los aspectos relativos al contenido, que el profesorado de ingeniería y arquitectura $(F(3,271)=8.557, p=.001)$.

Por lo que respecta a la lengua materna, el profesorado castellanohablante y catalanohablante consideró que los estudiantes llevan a cabo las actividades de escritura orientadas al proceso en menor medida que el profesorado de otras lenguas $(F(3,275)=3.616, p=.014)$. Por último, en relación con el género y los años de experiencia docente no se obtuvieron diferencias significativas en las variables analizadas. 


\section{Discusión y conclusiones}

En este primer artículo del monográfico nos ocupamos de presentar las características, fundamentación y estructura de la Encuesta Europea sobre la Escritura Académica (EEEA) y de describir las representaciones generales sobre la escritura académica de profesores y estudiantes relacionándolas con las características de los participantes, disciplinas y niveles educativos.

En relación a la Encuesta Europea sobre la Escritura Académica (EEEA) en sus dos versiones, para estudiantes y profesores, cabe destacar que los resultados obtenidos en la muestra española han revelado unos índices adecuados de fiabilidad de la mayoría de las escalas, lo que la convierte en un instrumento útil para describir las percepciones de los implicados en relación a la situación de la escritura en el contexto de enseñanza y aprendizaje universitario. Además, ninguno de los participantes indicó que su cumplimentación supusiera ninguna dificultad específica. El hecho de que varias de las escalas sean iguales en ambas versiones permite además contrastar con facilidad las percepciones de profesores y estudiantes en la mayoría de los aspectos analizados.

Los resultados relativos a las representaciones y sus relaciones con las características de los participantes indican que éstas se diferencian en relación al área disciplinar, más que en relación a las otras variables analizadas (género, lengua materna y nivel de experiencia). Tanto los profesores como los estudiantes de arte y humanidades y de ciencias sociales consideran que escriben más, están más orientados al proceso y reciben o dan más feedback, que el resto de áreas de conocimiento de nuestra muestra. Son resultados que confirman lo que ya se apuntaba en estudios anteriores en nuestro contexto (Castelló, Mateos et al., 2012; Mateos, Villalon, de Dios, \& Martín, 2007), y también en contextos diferentes (Chitez \& Kruse, 2012; Natale, 2012; Pérez-Abril \& Rodríguez, 2013). Resulta algo más sorprendente que la producción no se incremente con los años de estudio en la universidad, algo que sí contrasta con resultados recientes obtenidos en otros países (Delcambre \& Donahue, 2012), o la congruencia entre las representaciones de profesores y estudiantes, tanto en lo que concierne a las prácticas como a las competencias, tema controvertido en la investigación actual (Bazerman et al., 2012). En los artículos siguientes de este monográfico se profundiza en estas relaciones y se matizan algunas de las descripciones generales aquí apuntadas lo que permite un análisis más preciso de la situación de la escritura en la universidad española, necesario para su optimización.

Somos conscientes de las limitaciones del estudio que se deben, en gran medida, a su carácter inicial y exploratorio. En primer lugar, los participantes respondieron de manera voluntaria y se circunscriben a un espectro restringido de estudios y universidades; por lo tanto, no se trata de una muestra representativa. En segundo lugar, los datos recabados se basan en el uso de un único cuestionario, que, a pesar de ser un instrumento eficiente y útil para nuestro propósito, sólo da cuenta de lo que los participantes declaran, no de lo que realmente sucede en las aulas universitarias. Sin embargo, el gran número de participantes, especialmente en el caso de los estudiantes, además de su distribución en diferentes áreas geográficas del estado español, y su adscripción a diferentes tipologías de universidades, otorgan relevancia a los 
resultados y permiten que las tendencias y los análisis que se realizan en los diferentes artículos del monográfico, se erijan en una primera radiografía general de la situación actual de la escritura en el estado español, que, por supuesto, deberá completarse con estudios posteriores que precisen diferencias en función de colectivos específicos y garanticen su representatividad en estos colectivos. Algunos de estos estudios están ya en marcha en el seno de la Red.

\section{Acknoledgments / Agradecimientos}

The research reported has been partially funded by the Spanish Ministerio de Economía y Competitividad (DGICyT (CSO2013-41108-R y EDU2013-46606-C2_1-R) and the European Research Network on Learning to Write Effectively (ERN-LWE), COST Action IS0703). I Este estudio ha sido parcialmente financiado por el Ministerio de Economía y Competitividad español, DGICyT (CSO2013-41108-R y EDU2013-46606-C2_1-R) y la European Research Network on Learning to Write Effectively (ERN-LWE), COST Action IS0703.

\section{Disclosure statement}

No potential conflict of interest was reported by the authors.

\section{Notas}

1. European Research Network on Learning to Write Effectively (ERN-LWE). COST Action IS0703.

2. La RIEA-EA se creó en Junio de 2012, con el objetivo de compartir conocimiento, generar instancias de coordinación y analizar el estado de la cuestión de la investigación española en escritura académica en educación superior.

3. El cuestionario fue traducido siguiendo el método de traducción invertida en el que participaron investigadores nativos en ambas lenguas en cada etapa del proceso (backtranslation method (BTM).

4. En el anexo 1 de este artículo se puede consultar el cuestionario completo en sus dos versiones

5. Se trata del software gratuito para la confección de formularios proporcionado por Google

6. Aplicando las directrices de la R.A.E., y en aras de la economía expresiva, utilizamos el masculino plural para referirnos a colectivos de estudiantes de ambos sexos.

\section{References / Referencias}

Álvarez-Angulo, T. (1996). El texto expositivo-explicativo: su superestructura y características textuales. Didáctica de la lengua y la literatura, 8, 29-44.

Álvarez, M., Villardón, L., \& Yániz, C. (2008). Tareas de escritura en el ámbito universitario e implicaciones para el aprendizaje. Textos de didáctica de la lengua y la literatura, 49, 77-88.

Álvarez, M., Villardón, M. L., \& Yániz, C. (2010). Influencia de factores sociocognitivos en la calidad de la escritura en los estudiantes universitarios. Educatio Siglo XXI, 28, 181-204.

Applebee, A. (2013). Common core state standards: The promise and the peril in a national palimpsest. English Journal, 103, 25-33.

Applebee, A. N., \& Langer, J. A. (2013). Writing instruction that works: Proven methods for middle and high school classrooms. New York, NY: Teachers College Press. 
Bazerman, C. (1992). The informed writer. Using sources in the disciplines. Dallas: Houghton Mifflin.

Bazerman, C., Bonini, A., \& Figueiredo, D. (Eds.). (2009). Genre in a changing world. Perspectives on writing. Fort Collins, CO: The WAC Clearinghouse and Parlor Press. Retrieved March 25, 2014 from http://wac.colostate.edu/books/genre

Bazerman, C., Dean, C., Early, J., Lunsford, K., Null, S., Rogers, P., \& Stansell, A. (Eds.). (2012). International advances in writing research: Cultures, places, measures. Perspectives on writing. Fort Collins, Colorado: The WAC Clearinghouse and Parlor Press. Retrieved March 25, 2014, from http://wac.colostate.edu/books/ wrab2011

Bazerman, C., Little, J., Bethel, L., Chavkin, T., Fouquette, D., \& Garufis, J. (2005). Reference guide to writing across the curriculum. Indiana: Parlor Press.

Bereiter, C., \& Scardamalia, M. (1987). The psychology of written composition. Hillsdale, NJ: Erlbaum.

Britton, J. (1970). Language and learning. London: Allen Lane.

Camps, A., \& Castelló, M. (Coords.). (2013, May 1). Monográfico: Escritura académica// Academic writing. REDU. Revista de Docencia Universitaria, 11(1), 17-36. Retrieved from http://www.redu.net/redu/index.php/REDU/issue/view/70

Carroll, L. (2002). Rehearsing new roles: How college students develop as writers. Studies in writing and rhetoric. Carbondale: Southern Illinois University Press. Retrieved from http://wac.colostate.edu/books/rehearsing/

Casanave, C. P., \& Vandrick, S. (Eds.). (2003). Writing for scholarly publication: Behind the scenes in language education. Mahwah, NJ: Lawrence Erlbaum.

Castelló, M. (Coord.). (2007). Escribir y comunicarse en contextos científicos y académicos: conocimientos y estrategias. Barcelona: Graó.

Castelló, M. (2009). Escribir trabajos de investigación con alumnos de grado. Didáctica de la Lengua y de la Literatura, 50, 21-29.

Castelló, M., \& Donahue, C. (Eds.). (2012). University writing: Selves and texts in academic societies. Volume Series in Writing. Bingley, UK: Emerald group Publishing Limited.

Castello, M., Inesta, A., \& Corcelles, M. (2013). Learning to write a research article: $\mathrm{Ph}$. D. students' transitions toward disciplinary writing regulation. Research in the Teaching of English, 47(4), 442-477.

Castelló, M., Inesta, A., Pardo, M., Liesa, E., \& Martínez-Fernández, R. (2012). Tutoring the end-of-studies dissertation: Helping psychology students find their academic voice when revising academic texts. Higher Education, 63(1), 97-115. doi:10.1007/s10734-011-9428-9

Castelló, M., Mateos, M., Castells, N., Iñesta, A., Cuevas, I., \& Sole, I. (2012). Academic writing practices in Spanish universities. Electronic Journal of Research in Educational Psychology, 10(2), 569-590.

Chitez, M., \& Kruse, O. (2012). Writing cultures and genres in European higher education. In M. Castelló, \& C. Donahue (Eds.), University writing: Selves and texts in academic societies (pp.151-175). Volume Series in Writing. London: Emerald Group.

Chitez, M., Kruse, O., \& Castelló, M. (2015). The European writing survey (EUWRIT): Background, structure, implementation, and some results. Working Papers in Applied Linguistics, Hochschul-online-Publikationen ZHAW (forthcoming in September 2015)

Corcelles, M., Cano, M., Bañales, G, \& Vega, N. (2013). Enseñar a escribir textos científico-académicos mediante la revisión colaborativa: El trabajo final de grado en Psicología. REDU: Revista de Docencia Universitaria, 11(1), 79.

Corcelles, M., Oliva, À., Castelló, M., Milian, M. (2015). Writing at university: are we on the same page?

Delcambre, I., \& Donahue, C. (2012). Academic writing activity: Student writing in transition. In M. Castelló, \& C. Donahue (Eds.), University writing: Selves and texts in academic societies (pp. 129-150). Volume Series in Writing. London: Emerald Group. 
Dysthe, O. (2012). Multivoiced classrooms in higher education academic writing. In M. Castelló, \& C. Donahue (Eds.), University writing: Selves and texts in academic societies (pp. 201-216). Volume Series in Writing. London: Emerald Group.

Gardner, S., \& Nesi, H. (2013). A classification of genre families in university student writing. Applied Linguistics, 34(1), 25-52. doi:10.1093/applin/ams024

Hyland, K. (2005). Stance and engagement: A model of interaction in academic discourse. Discourse Studies, 7(2), 173-192. doi:10.1177/1461445605050365

Hyland, K. (2008). 'Small bits of textual material': A discourse analysis of Swales' writing. English for Specific Purposes., 27, 143-160. doi:10.1016/j.esp.2006.10.005

Iñesta, A., \& Castelló, M. (2012, July 20). Towards an integrative unit of analysis: Regulation episodes in expert research article writing (Chapter, 24). In C. Bazerman, C. Dean, J. Early, K. Lunsford, S. Null, P. Rogers, \& A. Stansell (Eds.), International advances in writing research: Cultures, places, measures (pp. 421-448). Retrieved from http://wac.colostate.edu/books/wrab2011/chapter24.pdf

Ivanič, R. (1998). Writing and identity: The discoursal construction of identity in academic writing. Amsterdam: John Benjamins. doi:10.1075/swll.5

Kruse, O. (2013). Perspectives on academic writing in European higher education: Genres, practices, and competences. REDU. Revista de Docencia Universitaria, 11 (1), 37-58.

Kruse, O., \& Chitez, M. (2012). Contrastive genre mapping in academic contexts: An intercultural approach. Journal of Academic Writing, 2(1), 59-73.

Lavelle, E., \& Zuercher, N. (2001). The writing approaches of university students. Higher Education, 42(3), 373-391. doi:10.1023/A:1017967314724

Lea, M. (2012). New genres in the academy: Issues of practice, meaning making and identity. In M. Castelló, \& C. Donahue (Eds.), University writing: Selves and texts in academic societies (pp. 93-109). Volume Series in Writing. London: Emerald Group.

Lea, M., \& Stierer, B. (2000). Student writing in higher education. New contexts. Buckingham: SRHE \& Open University Press.

Lea, M., \& Street, B. V. (1998). Student writing in higher education: An academic literacies approach. Studies in Higher Education, 23(2), 157-172. doi:10.1080/ 03075079812331380364

Lillis, T. (1997). New voices in academia? The regulative nature of academic writing conventions. Language and Education, 11(3), 182-199. doi:10.1080/09500789708666727

Lonka, K., Chow, A., Keskinen, J., Hakkarainen, K., Sandström, N., \& Pyhältö, K. (2014). How to measure PhD students' conceptions of academic writing - and are they related to well-being? Journal of Writing Research, 5(3), 245-269. doi:10.17239/ jowr-2014.05.03.1

Mateos, M., Cuevas, I., Martín, E., Martín, A., Echeita, G., \& Luna, M. (2011). Reading to write an argumentation: The role of epistemological, reading and writing beliefs. Journal of Research in Reading, 34, 281-297. doi:10.1111/j.1467-9817.2010.01437.x

Mateos, M., \& Solé, I. (2009). Synthesising information from various texts: A study of procedures and products at different educational levels. European Journal of Psychology of Education, 24(4), 435-451. doi:10.1007/BF03178760

Mateos, M., Solé, I., Martín, E., Miras, M., Cuevas, I., \& Castells, N. (2014). Writing a synthesis from multiple sources as a learning activity. In P. Klein, P. Boscolo, L. Kirkpatrick, \& C. Gelati (Eds.), Studies in Writing Series: Vo.28, Writing as a learning activity (pp. 169-190). Leiden: Brill. doi:10.1163/9789004265011_009

Mateos, M., Villalón, R., de Dios, M. J., \& Martín, E. (2007). Reading and writing tasks on different university degree courses: What do the students say they do? Studies in Higher Education, 32(4), 489-510. doi:10.1080/03075070701476183

Natale, L. (Ed.). (2012). En carrera: Escritura y lectura de textos académicos y profesionales. Los Polvorines: Universidad Nacional de General Sarmiento. Retrieved from http://www.ungs.edu.ar/prodeac 
Oliva, A., \& Milian, M. (2013). First year students' construction of an academic identity in English as a foreign language. Revista de Docencia Universitaria. REDU. Número monográfico dedicado a Academic Writing, 11(1), 59-77. Retrieved March 23, 2014, from http://www.red-u.net/

Perea, F. J. (Coord.). (2013). Comunicar en la universidad. Descripción y metodología de los géneros académicos. Córdoba: Ediciones de la Universidad de Córdoba.

Pérez-Abril, M., \& Rodríguez, A. (2013). ¿Para qué se lee y se escribe en la universidad colombiana? Caracterización de prácticas de lectura y escritura en 17 universidades. Revista de Docencia Universitaria. REDU. Número monográfico dedicado a Academic Writing, 11(1), 137-160. Retrieved March 25, 2014, from http://www.red-u.net/

Robinson-Pant, A., \& Street, B. (2012). Students' and tutors' understanding of 'new' academic literacy practices. In M. Castelló, \& C. Donahue (Eds.), University writing: Selves and texts in academic societies (pp. 71-92). Volume Series in Writing. London: Emerald Group.

Roca de Larios, J. R., \& Serrano, S. L. (2011). Consideraciones prácticas sobre la elaboración del portafolios del estudiante: su aplicación al aprendizaje de la pronunciación del inglés. Didáctica. Lengua y Literatura, 23, 349-367. doi:10.5209/ rev_DIDA.2011.v23.36322

Russell, D. R. (1991). Writing in the academic disciplines, 1870-1990: A curricular history. Carbondale, IL: Southern Illinois University Press.

Russell, D. R. (1997). Rethinking genre in school and society: An activity theory analysis. Written Communication, 14, 504-554. doi:10.1177/0741088397014004004

Russell, D. R., Lea, M., Parker, J., Street, B., \& Donahue, C. (2009). Exploring notions of genre in 'academic literacies' and 'writing across the curriculum': Approaches across countries and contexts. In C. Bazerman, A. Bonini, \& D. Figueiredo (Eds), Genre in a changing world. Perspectives on writing (pp. 459-491). Colorado: WAC Clearinghouse/Parlor Press.

Solé, I., Mateos, M., Miras, M., Martín, E., Castells, N., Cuevas, I., \& Gràcia, M. (2005). Lectura, escritura y adquisición de conocimientos en educación secundaria y educación universitaria. Infancia y Aprendizaje, 28, 329-347. doi:10.1174/ 0210370054740241

Solé, I., Teberosky, A., \& Castelló, M. (2012, August 30). Academic communication strategies in postgraduate studies. In C. Thaiss, G. Bräuer, P. Carlino, L. GanobcsikWilliams, \& A. Sinha (Eds.), Writing programs worldwide: Profiles of academic writing in many places. Fort Collins, CO: WAC Clearinghouse and Parlor Press. Retrieved from http://wac.colostate.edu/books/wrab2011/

Swales, J. (2004). Research genres. Exploration and applications. Cambridge: Cambridge University Press. doi:10.1017/CBO9781139524827

Tolchinsky, L. (coord.). (2013). La escritura académica en las disciplinas. Barcelona: Octaedro/ICE.

Villalón, R., \& Mateos, M. (2009). Concepciones del alumnado de secundaria y universi- 1005 dad sobre la escritura académica. Infancia y Aprendizaje, 32(2), 219-232. doi:10.1174/021037009788001761

Walvoord, B., \& McCarthy, L. (2008). Thinking and Writing in College: A Naturalistic Study of Students in Four Disciplines. WAC Clearinghouse Landmark Publications in Writing Studies: http://wac.colostate.edu/books/thinkingwriting/ Originally Published in Print, 1990, by National Council of Teachers of English, Urbana, Illinois.

White, M. J., \& Bruning, R. (2005). Implicit writing beliefs and their relation to writing quality. Contemporary Educational Psychology, 30, 166-189. doi:10.1016/j. cedpsych.2004.07.002 